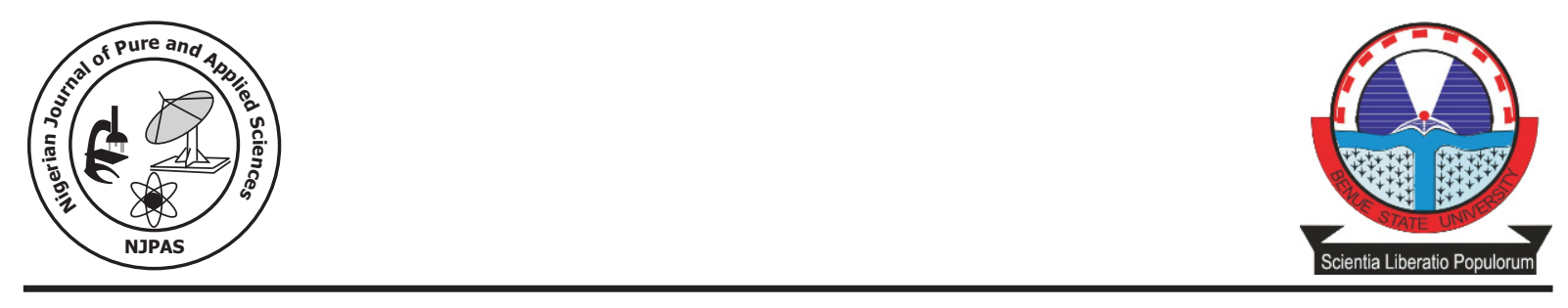

\title{
Measurement of Environmental Radioactivity within Dangote Cement Escavation Site Gboko, Benue State.
}

\author{
Tyovenda, A. A, ${ }^{1}$, Akombor, A. A. ${ }^{2}$ and Tamaugee, S. $\mathrm{T}^{3}$ \\ 1. Department of Physics, University of Agriculture Makurdi, Benue State-Nigeria ${ }^{1}$ \\ 2. Department of Physics, Benue State University, Makurdi, Benue State-Nigeria². \\ 3. Department of Physics, Federal College of Education Kontagora, Niger State-Nigeria ${ }^{3}$
}

Corresponding Author: alexgbeh@yahoo.com.+2348062436431

\begin{abstract}
The radioactivity of rocks from Dangote Cement excavation site in Gboko, Benue State were monitored and measured using the radiation meter inspector 06250 and dose meter 6150AD 2/4/6. The meters measure the dose rate, exposure rate and the activity. The meters were held 1 meter above the surface of the soil at the excavation site. Each reading was taken 10 times at varying distances between zero and 100 meters from the excavation site after which the mean readings for each of the distance were then found. Finally, the background count was taken 200 meters away from the excavation point. The highest value of dose equivalent rate of $0.428 \pm 0.006 \mathrm{mSv} / \mathrm{yr}$, exposure rate of $0.206 \pm 0.003 \mathrm{mR} / \mathrm{hr}$ and activity of $6.8 \pm 0.4 \mathrm{kBq}$ were measured at zero distance from the excavation point while the least value of dose equivalent rate of $0.212 \pm 0.002 \mathrm{mSv} / \mathrm{yr}$, exposure rate of $0.081 \pm 0.001 \mathrm{mR} / \mathrm{hr}$ and activity of $3.2 \pm 0.8 \mathrm{kBq}$ were obtained at 100 meters away from the excavation point. The result shows that the excavation site is within the safety limit set by the international commission on Radiological protection (ICRP) (1990).
\end{abstract}

Keywords: Dose equivalent rate, exposure rate, radioactivity, background radiation.

\section{Introduction}

Radioactivity is the release of energy in the form of gamma rays and energetic particles (alpha and beta particles) that occurs when unstable elements decompose to form more stable elements (IAEA, 1986). The process by which an element changes from an unstable state to a more stable state by emitting radiation is called radioactive decay. Gamma rays, alpha particles, and beta particles, which are given off by radioactive decay, have very different properties but are all ionizing radiation - each is energetic enough to break chemical bonds, thereby possessing the ability to damage or destroy living cells (Bushberg et al., 2002).

Mining is one of the oldest industries in Nigeria and it include tin mining, coal mining, uranium mining, limestone mining, clay mining and so on. Mining in Nigeria date back to the beginning of the century, but its radiological awareness comes in only recently (Sanni, 1970). High radiation levels may occur in these mines, since the product of the mines are naturally radioactive. During refining, the radioactive substances are expelled into the environment. Such radiation, stem from radioactive nuclides dissociated from the ores (Jirbiri and Farai, 1999). These nuclides release alpha, beta and 
gamma rays, all of which are ionizing radiation. If the dose rate of exposure from these mines exceeds the recommended maximum radiation dose to the public, which is $1 \mathrm{mSv} / \mathrm{yr}$, then it becomes a hazard (ICRP, 1990).

In solid mineral industry there exists risks in the mining and processing due to potential hazards arising from radioactive minerals. This beneficial human activity (mining) increases the background radiation already in existence (Sanni, 1977). Radiation hazard associated with the mines arise mainly from radiation and surface contamination of these mines and absorbed dose rate from airborne radiation and from the dumps in some mills. Natural occurring radioactive elements occur in almost all common rock types and minerals (Lappenbush and Cothern, 1985).

Thus, for health physics purposes, a conservative upper limit of the relative biological effectiveness (RBE) for the geological effect of greatest interest to humans due to a radiation is used as a normalizing factor in adding doses from different radiations. The equivalent dose $\mathrm{H}_{\mathrm{T}}, \mathrm{S}_{\mathrm{v}}$, in tissue or organ $\mathrm{T}$, is defined by the ICRP as

$$
\mathrm{H}_{\mathrm{T}}=\mathrm{W}_{\mathrm{R}} \times \mathrm{D}_{\mathrm{T}}, \mathrm{R}
$$

Where $\mathrm{D}_{\mathrm{T}}, \mathrm{R}$, is the absorbed dose, expressed in grays, average over the tissue or organ $T$, due to radiation $R$ and $W_{R}$ is the weighting factor.

\section{Study Area}

The study area Dangote Cement which is located in Gboko is found in Benue State, North Central Nigeria. Situated on longitude $9.0^{\circ} \mathrm{E}$ and latitude $7.0^{\circ} \mathrm{N}$ and $7.50^{\circ} \mathrm{N}$. Gboko is a densely populated area inhabited dominantly by average - life dwellers.

\section{Materials and Methods}

The instruments used for measurement in this research work are the Radiation meters, inspector 06250 which was used to measure Exposure Rate $(\mathrm{mR} / \mathrm{hr})$ and Activity $(\mathrm{kBq})$ and Dose Meter 6150 AD 2/4/6 was used to measure Dose equivalent rate $(\mathrm{mSv} / \mathrm{yr})$. These are radiation instruments that have in-built calibration mechanisms for the measurement of alpha, beta, gamma and X-rays. The inspector 06250 and Dose meter 6150 AD 2/4/6 measures the dose rate, exposure rate and activity. The choice of these meters was as the result of their portability, sensitivity and their response, which are appropriate since these are low radiation field.

The method of radiation measurement employed in this work, was the direct observation and measurement of radiation from the excavation site using the radiation detectors. These detectors were held one meter above the radioactive sources at various distances of the mining excavation site of Dangote Cement Factory Gboko, after which the mean of the readings were then found. Finally, the background count was taken 200 meters from the excavation site.

\section{Results and Discussion}

The results of the dose rate $(\mathrm{mSv} / \mathrm{yr})$, exposure rate $(\mathrm{mR} / \mathrm{hr})$, activity $(\mathrm{kBq})$ are presented in tables 1,2 and 3 and the analysis as in figs. 1, 2 and 3 respectively.

Table 1: Dose equivalent rate $(\mathrm{mSv} / \mathrm{yr})$ at varying distances from the excavation point.

\begin{tabular}{lll}
\hline S/No & $\begin{array}{l}\text { Dose equivalent rate } \\
(\mathrm{mSv} / \mathrm{yr})\end{array}$ & Varying distance $(\mathrm{m})$ \\
\hline 1 & $0.428 \pm 0.006$ & 00.00 \\
2 & $0.402 \pm 0.004$ & 20.00 \\
3 & $0.358 \pm 0.002$ & 40.00 \\
4 & $0.322 \pm 0.005$ & 60.00 \\
5 & $0.296 \pm 0.008$ & 80.00 \\
6 & $0.212 \pm 0.002$ & 100.00 \\
\hline
\end{tabular}


Table 2: Exposure Rate $(\mathrm{mR} / \mathrm{hr})$ at varying distances from the excavation point.

\begin{tabular}{lll}
\hline S/No & Exposure Rate $(\mathrm{mR} / \mathrm{hr})$ & Varying distance $(\mathrm{m})$ \\
\hline 1 & $0.206 \pm 0.003$ & 00.00 \\
2 & $0.212 \pm 0.004$ & 20.00 \\
3 & $0.183 \pm 0.001$ & 40.00 \\
4 & $0.142 \pm 0.002$ & 60.00 \\
5 & $0.094 \pm 0.003$ & 80.00 \\
6 & $0.081 \pm 0.001$ & 100.00 \\
\hline
\end{tabular}

Table 3: Activity $(\mathrm{kBq})$ at varying distances from the excavation point

\begin{tabular}{lll}
\hline S/No & Activity $(\mathrm{kBq})$ & Varying distance $(\mathrm{m})$ \\
\hline 1 & $6.8 \pm 0.4$ & 00.00 \\
2 & $5.4 \pm 0.6$ & 20.00 \\
3 & $5.0 \pm 0.8$ & 40.00 \\
4 & $4.4 \pm 0.6$ & 60.00 \\
5 & $3.9 \pm 0.5$ & 80.00 \\
6 & $3.2 \pm 0.4$ & 100.00 \\
\hline
\end{tabular}

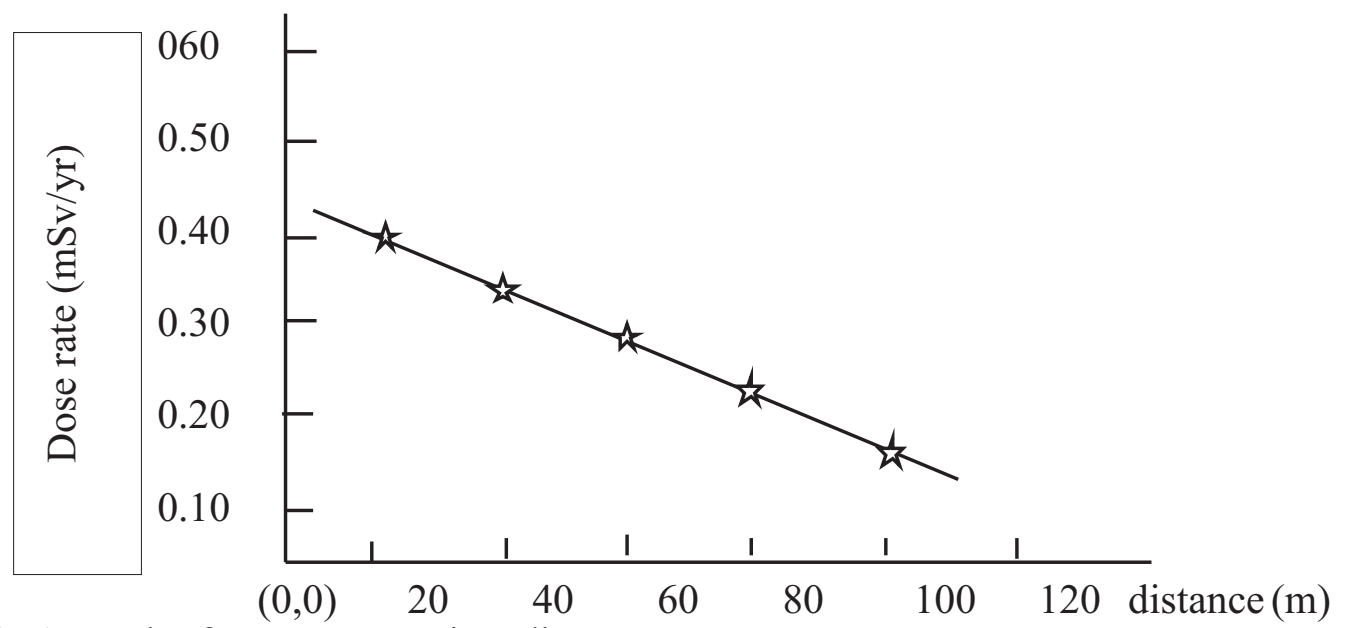

Fig. 1: A graph of Dose rate against distance

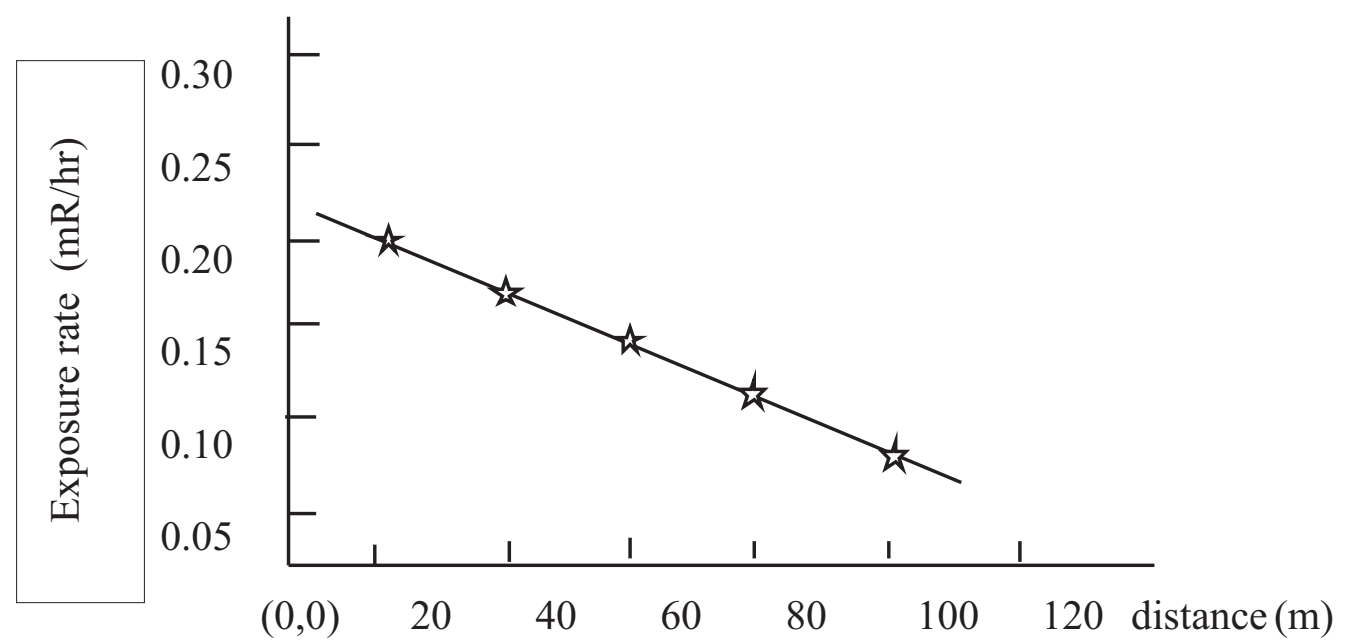

Fig. 2: A graph of Exposure rate against distance 


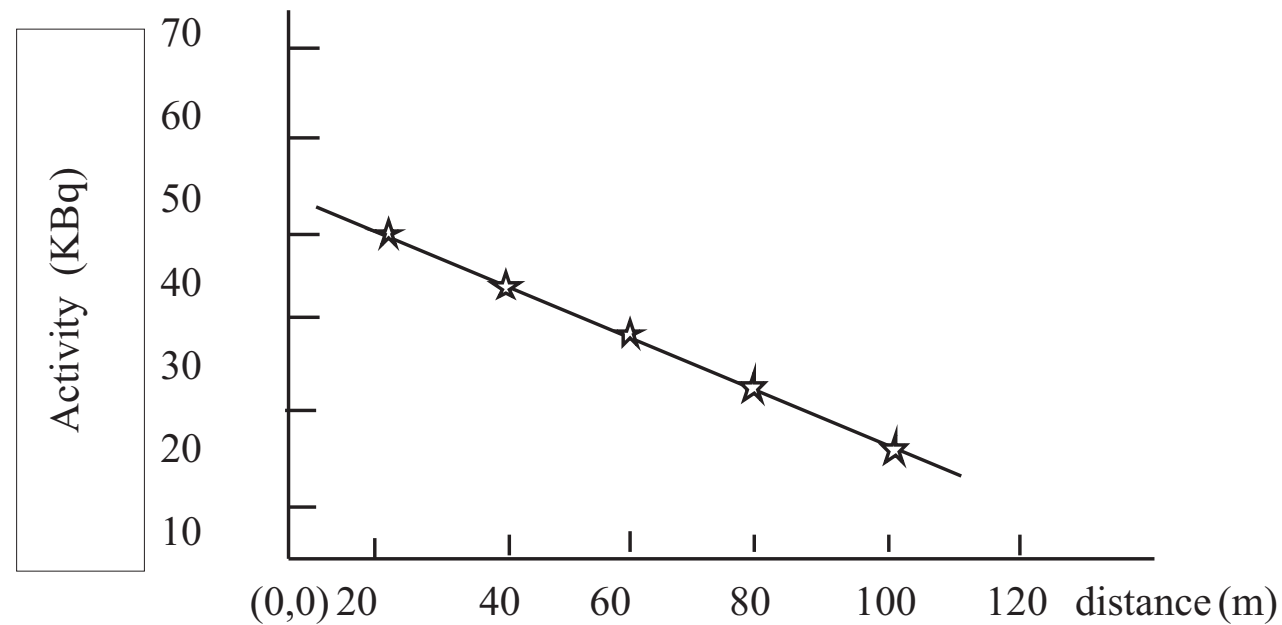

Fig. 3: A graph of Activity rate against distance

The result of the dose equivalent rate $(\mathrm{mSv} / \mathrm{yr})$ at varying distances obtained from the excavation point shows that at zero distance (within the excavation point0 the dose equivalent rate has a maximum value of $0.428 \pm 0.006 \mathrm{mSv} / \mathrm{yr}$ and a minimum value of $0.212 \pm 0.002 \mathrm{mSv} / \mathrm{yr}$ at a distance of $100 \mathrm{~m}$ from the excavation point. The relatively high values of the dose equivalent rate beyond the background radiation levels may be due to the presence of some traces of radioisotopes of uranium, potassium and thorium which are normally found in granitic rocks (Jirbiri and Farai, 1999), these are known as emitters of gamma and beta radiation (Glowaik and Pacyna, 1980). The gradual decrease of radioactivity as one move away from the excavation point is as a result of variation in the energy and distance travelled by various radioactive sources like beta, alpha and gamma rays [1], this can be seen as shown in Fig. 1.1 above.

Similarly the result of the exposure rate $(\mathrm{mR} / \mathrm{hr})$ as measured from the excavation site has a maximum value of $0.2120 .212 \pm 0.004$ $\mathrm{mR} / \mathrm{hr}$ and a minimum value of $0.0810 .212 \pm 0.001 \mathrm{mR} / \mathrm{hr}$ at distances of $20 \mathrm{~m}$ and $100 \mathrm{~m}$ respectively. Also the result of the activity $(\mathrm{kBq})$ has a maximum value of $6.8 \pm 0.4 \mathrm{kBq}$ at zero distance at the excavation point and a minimum value of $3.2 \pm 0.4 \mathrm{kBq}$ at $100 \mathrm{~m}$ from the excavation point. Both values are beyond the background readings taken at a distance of $200 \mathrm{~m}$ from the excavation point.

The relative high values of the exposure rate and activity is in good agreement with the associated high values of the dose equivalent rate and this may be due to the presence of some traces of uranium, potassium and Thorium which are emitters of gamma and beta radiations (Glowaik and Pacyna, 1980).

The graphs of dose rate $(\mathrm{mSv} / \mathrm{yr})$, exposure rate $(\mathrm{mR} / \mathrm{hr})$ and activity $(\mathrm{kBq})$ against distance as in Fig. 1,2, and 3 all show a linear decrease in measured values, which may be due to the inability of certain ionizing radiations particles to travel beyond specified distances and the energy posses by the particles.

\section{Conclusion}

This work has established the presence of ionizing radiation from Dangote Cement excavation site, Gboko. Since the ambient radiation levels from the site is above the background values. However, the highest dose equivalent rate of $0.428 \pm 0.006 \mathrm{mSv} / \mathrm{yr}$ measured at the excavation point is still within the safety limit of $1.0 \mathrm{mSv} / \mathrm{yr}$ as set by the international commission on radiological protection (ICRP) for the general public since these factory/mine workers cannot be considered as radiation workers. The information obtained from the excavation site is essential for planning purposes regarding radioactivity levels and related hazard at the 
site and its environment. Thus in order to avoid over exposure, workers at the excavation site are advised to avoid prolong work schedules until further work is done to isolate the radiological isotopes within the granitic rock formations.

\section{References}

Bushberg, J.T., Seibert, J.A., Leidholdt, E.D. and Boone, J.M. (2002). The essential Physics of Medical imaging. Second edition; Philadelphia, Lippincott Williams and Wilkins. Pp. 627-753.

Glowaik, B.J. and Pacyna, J.M. (1980). Radiation dose due to atmospheric release from coal fired power plants. Health physics, 16:23-28.

International Atomic Energy Agency (1986).

Facts about low level radiation exposure, IAEA publication No. A.N. E985-06482.

International Commission on radiological Protection (1990). The evaluation of risks from radiation. Proceedings of (ICRP) Publication, Peragamon Press.

Jirbiri, N.N. and Farai, I.P. (1999). Radioactivity levels of some Nigerian rock samples. Nigeria Journal of Physics, 2(1): 22-25.

Lappenbusch, W.L. and Cothern, C.R. (1985). Regulatory development of the interim and revised regulation for radioactivity in drinking water-past and present issues and problems. Health Physics, 48(5): 535-551.

Sanni, A.O. (1970). Report on the radiation hazard in the mines of Jos area. Federal Radiation protection service. Annual Report pp. 1-4.

Sanni, A.O. (1977). A brief review of high natural background areas in Nigeria, proceeding of international symposium on Areas of High Radioactivity, Rio de Janeiro, p. 136. 